\title{
The Effect of Imperfections on Crack Growth Rates in Cold Worked and Interference Fit Holes
}

\author{
Cameron Coates ${ }^{1)}$ \\ Ved Vakharia ${ }^{2)}$
}

\begin{abstract}
This work examines the effect of imperfections on fatigue crack growth (FCG) in lap joints (Hi-Lok fasteners). The Finite Element Method (FEM) is used to model the cold-working and interference fit processes. FE predictions are shown to be consistent with experimental and computational results in the literature. The Extended Finite Element Method (XFEM) is then used to simulate a Mode I through crack in a rectangular plate starting at the fastener hole subjected to cold-working and interference fit. Four constant load ratio fatigue cases are investigated: (i) no residual stress, no imperfection, (ii) no residual stress, imperfection, (iii) residual stress, no imperfection and (iv) residual stress, imperfection. XFEM predictions used with the Walker equation predict that the presence of an axial gouge within a hole may result in a significant decrease (23\%) in the component fatigue life under constant amplitude cyclical loading. This decrease appears to be exacerbated if a residual compressive stress field due to cold-work and interference fit is present
\end{abstract}

Key words: fatigue, crack, fastener, cold work, interference, finite element.

\section{Introduction}

$\mathrm{B}$ OTH military and civilian airlines have a vested interest in extending the lives of aircraft within their current fleets, many of which will be 25-30 years old, as of 2018 . Maintaining the structural integrity of ageing aircraft is paramount to their continued operation. One of the most common causes of structural failure among ageing aircraft is fatigue crack instability. Bolted and riveted lap joints are particularly vulnerable to fatigue failure for several reasons. These reasons include: a higher probability of fretting wear due to plate contact, improperly installed fasteners or rivets, higher stress intensities due to the presence of countersunk holes, undesirable residual stresses induced during the manufacturing or installation process, and a higher sensitivity to damage from maintenance mishaps (for example scratches or grooves near the fastener hole due to accidental tooling impact). Most lap joints within aircraft structures are also subject to bending loads and fuselage pressurization, which may exacerbate crack growth.

Interference fit and cold working are effective methods used to improve the fatigue life of lap joints [1-3]. For the -cold working case, improvement is obtained through the generation of a compressive residual stress field just beyond the enlarged (and plastically deformed) region along the hole perimeter. If the fit is an interference fit, compressive stresses will also develop near the hole, however plastic deformation may not necessarily take place. In both cases, the compressive residual stresses inhibit mode I crack growth in the vicinity of the hole, thereby increasing fatigue life. Many researchers have sought to predict the magnitude, geometry and behavior of these residual stress fields using experiments, computational and/or theoretical models. Bi et al. conducted experiments to measure the squeeze force and strains (due to tensile loading) in a bolted lap joint for various interference fits [4]. Predictions from their 3D Finite Element (FE) model compared reasonably well with their experimental results. These authors concluded that, as the interference fit increases, the minimum principal stress in the vicinity of the hole increases, and the maximum principal stress decreases. Zheng et al. [5] developed a theoretical model of the residual stress field for riveted holes that takes into consideration the radial pressure at the hole boundary, the strain hardening effect of the rivet material and the springback process. Fatigue life estimates of the riveted joints based on residual stress values obtained from their model were in good agreement with experimental results. Garcia et al. developed three Finite Element (FE) Fatigue Crack Growth (FCG) models of a rectangular specimen of 7050-T7541 aluminum alloy under four-point bending [6]. The model types were: linear elastic, linear elastic with crack closure, and elastic-plastic with crack closure. Predictions from the elastic-plastic FE model with crack closure effects matched experimental results very well, for the FCG with positive applied stress ratios. These authors concluded that the negative part of the stress cycle with a fully closed crack (elastic-plastic model) does contribute to the driving force for FCG.

Of interest is the role of imperfections on the fatigue behavior of joints that utilize fasteners. The presence of an imperfection can be expected to increase stress intensity locally. As a fatigue crack grows, any residual stress field due to interference and cold-working will redistribute. The presence of an imperfection therefore complicates this redistribution and may have an adverse effect on the expected fatigue life. The type of imperfection (for example, an axial gouge or an edge burr) will also influence the

\footnotetext{
1) Southern Polytechnic College of Engineering and Engineering Technology, Kennesaw State University Marietta GA 30060

2) Materials Science and Engineering Program University of California San Diego, La Jolla, CA 92093

Correspondence to: Cameron Coates, e-mail: ccoates4@kennesaw.edu
} 
residual stress redistribution, and hence the fatigue life. Jury et al. conducted fatigue tests on fuselage crown skin lap joints removed from a retired narrow-bodied commercial aircraft near its design service goal of 60,000 flight cycles [7]. These researchers showed that a single hole quality parameter correlated very well with crack size when rivet fit installation was within specification. Atre conducted experiments and developed FE models using the same data to investigate the role of several imperfections (found from the tear down inspection in Jury et al.'s work) on the fatigue life of riveted lap joints [8]. No studies that investigate the effect of imperfections on lap joints that utilize Hi-Lok fasteners were found in the literature. This work examines the effect of imperfections on FCG in the vicinity around holes for lap joints that utilize Hi-Lok fasteners. A Finite Element Method is initially developed which models the interference bolt installation and the cold-expansion processes. The subsequent crack growth model therefore incorporates the residual stress redistribution as the crack grows and the plastic strain history due to cold working and interference. Four fatigue cases are investigated: (i) no residual stress, no imperfection, (ii) no residual stress, imperfection, (iii) residual stress, no imperfection and (iv) residual stress, imperfection. The Extended Finite Element Method (XFEM) available in the commercial software ABAQUS is used to simulate a Mode I through crack in a rectangular plate starting at the fastener hole [9]. Stress intensity values for each increment of crack growth are then determined and used to predict component fatigue life with and without an imperfection.

\section{Method}

\section{FE Cold Expansion}

Kang et al. [10] developed a three-dimensional finite element model for the cold expansion process in Al 7050T7451 and 2024-T351. Their model achieved very good agreement with experimental data results. The current model (Al 7050-T741) developed in this work uses the same material and geometric properties, as well initial and boundary conditions used in Kang et al. Due to the radial symmetry of the mechanical behavior resulting from the cold-working process, a quarter plate model was implemented to represent the entire hole. The 8-node linear brick, reduced integration, hourglass control C3D8R mesh element type was selected for the analysis. The model contained 31,800 elements and 34,892 nodes. The analysis method was broken up into two steps: (1) uniform displacements are applied to each node at the face of the hole corresponding to a $4 \%$ expansion, (2) the hole was allowed to recover, simulating the removal of the mandrel from the hole. This was done by removing all the displacement boundary conditions.

\section{FE Interference Fit}

Bi et al. [4] conducted experiments to determine how the magnitude of interference fit affects residual stresses. These authors also developed a three-dimensional finite element model which compared very well with their experimental data of the squeeze forces and the strains. The current model uses the same material and geometric properties and boundary conditions used for the FE model in $\mathrm{Bi}$ et al. $\mathrm{Al}$ 7050-T7451 and Ti-6Al-4V were used as the materials for the plate and the Hi-LOK bolt, respectively. Interference fit values of $0.5 \%, 1 \%, 1.5 \%$, and $2 \%$ were applied to the hole. The 8-node linear brick, reduced integration, hourglass control C3D8R mesh element type was used for the analysis. The model contained 45,339 elements and 57,554 nodes. The process of the interference fit is modeled in one step. The bolt was placed in the hole such that only the portion of the bolt with the small diameter (before the transition region) was in the hole. Images of the model before and after the interference fit step is shown in Fig.1.

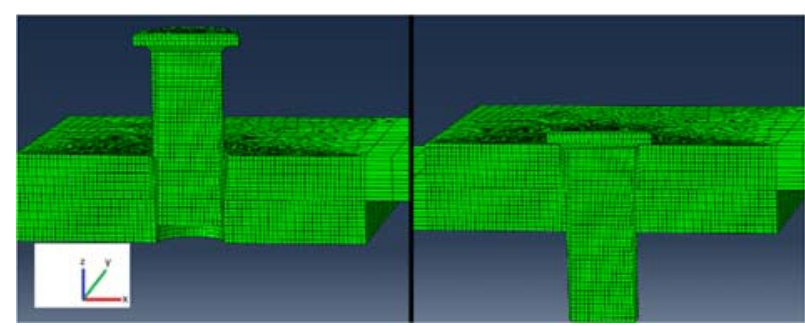

Figure 1. Before (left) and after (right) images of interference fit step

\section{Combining Models}

The residual stress fields from cold-working model were used as an initial condition for the interference fit model. The resulting residual stress fields were then used as initial conditions for a crack growth model using the Extended Finite Element Method (XFEM).

\section{XFEM Model}

The XFEM model uses a rectangular plate with geometry and loading consistent with the middle splice in the three splice lap joint system at the upper aft longeron-outer mold line fastener hole for a USAF F-15C aircraft. The crack location and plate geometry are shown in Figures 2(a) and 2(b), respectively. The axial gouge was modeled as a triangular prism as shown in detail A in Fig.2(b). In service stress gradients of maximum/minimum principal stresses along the crack path and a load spectrum obtained from the aircraft manufacturer were used to provide realistic applied load conditions to the model. Figures 3(a) and 3(b) show the load boundary conditions and the full XFEM model, respectively. The ABAQUS XFEM model consisted of 66,607 C3D8R elements. The C3D8R element is an 8-noded linear brick element, employing reduced integration with hourglass control. The material was modeled as elasticplastic with kinematic hardening. Material properties are provided in Table 1. After testing for convergence, an element size of 0.01 inch was chosen.

Table 1. Material Properties

\begin{tabular}{||c|c||}
\hline \multicolumn{2}{|c||}{ Material: Al 7050-T7451 } \\
\hline \multicolumn{2}{|c||}{ Elastic Properties } \\
\hline Young's Modulus (MPa) & Poisson's ratio \\
\hline 71800 & 0.33 \\
\hline \multicolumn{2}{|c||}{ Plastic Properties } \\
\hline Yield Stress (MPa) & 0 \\
\hline 443.955 & 0.00134 \\
\hline 453.417 & 0.00258 \\
\hline 457.541 & 0.0237 \\
\hline 488.056 & 0.0437 \\
\hline 502.902 & 0.0936 \\
\hline 521.046 & Plastic Strain \\
\hline
\end{tabular}




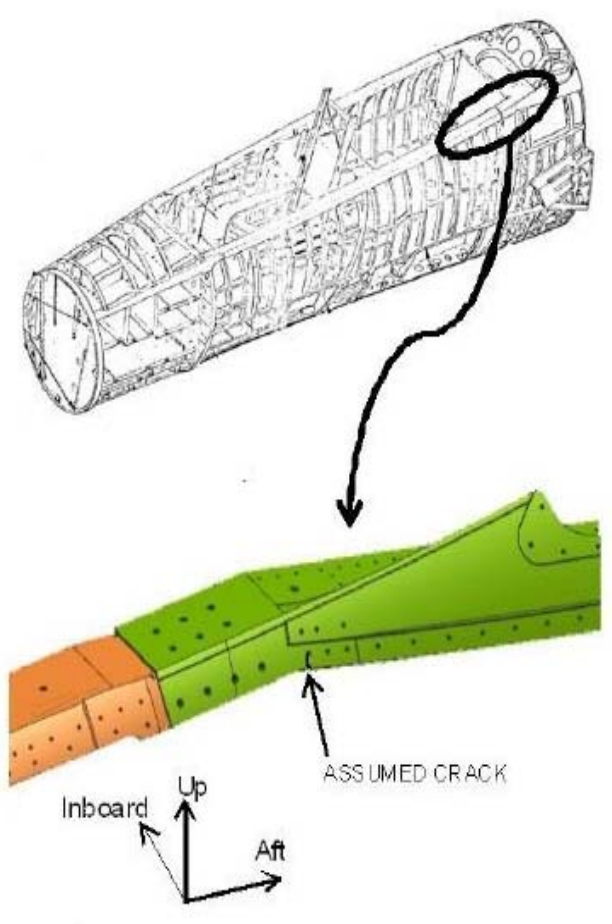

Figure 2a. Crack location in component

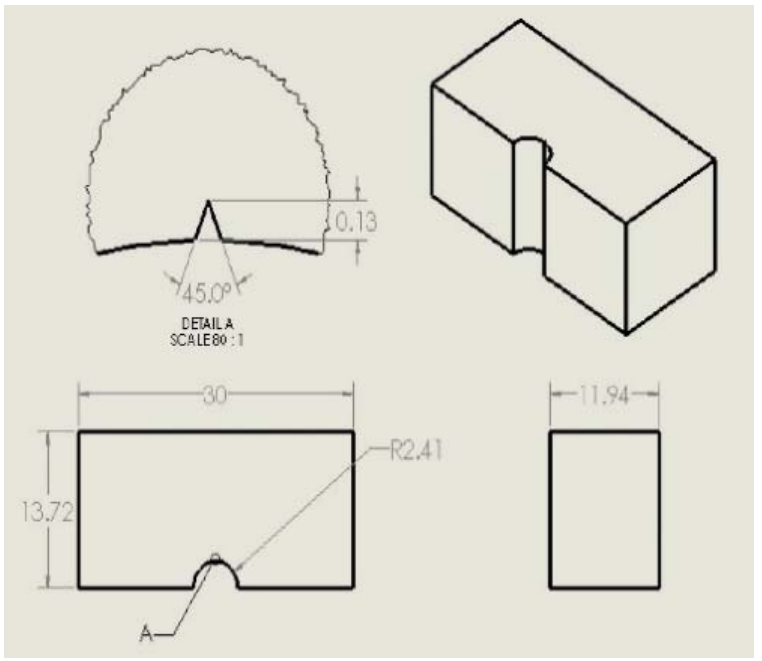

Figure 2b. Plate Geometry (dimensions in $\mathrm{mm}$ )

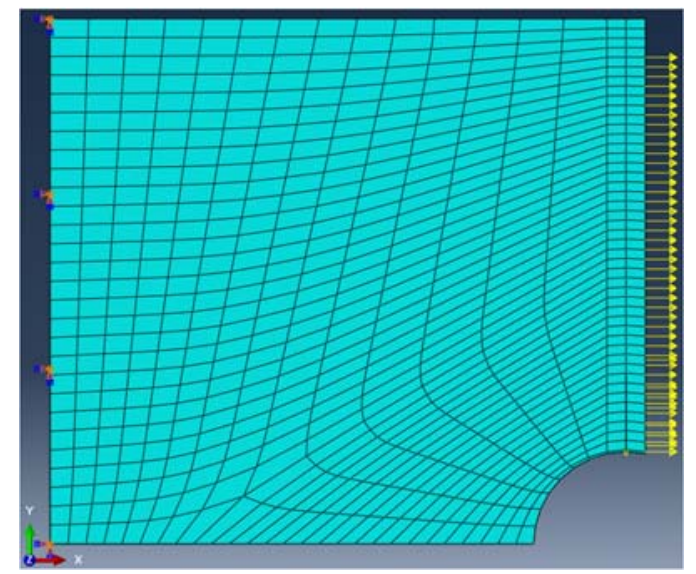

Figure 3a. Boundary Conditions for XFEM Crack

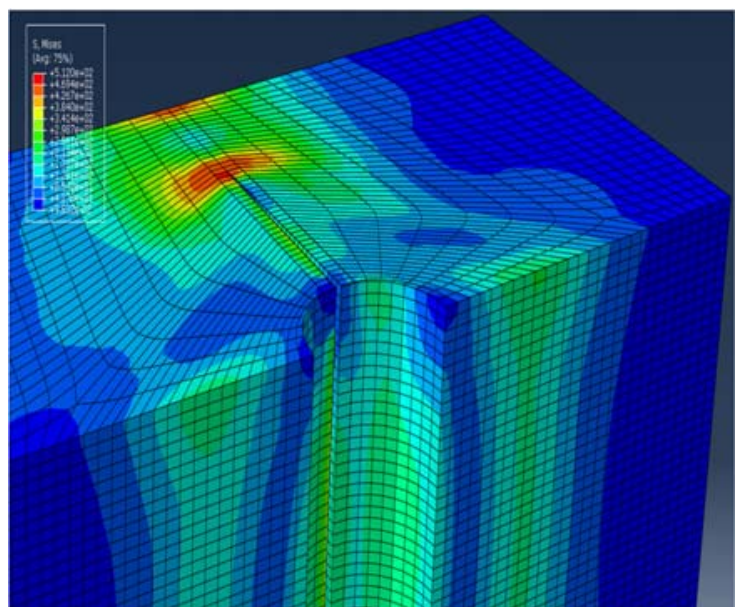

Figure 3b. XFEM model: crack opening

\section{Theoretical Approach}

\section{Traditional Fatigue Approach}

In the current traditional method of establishing a safe life, an assumption that a $0.05 \mathrm{in}$. $(1.27 \mathrm{~mm})$ crack already exists in the structure is made. Principal stresses (resulting from expected flight loads) that drive fatigue crack growth within the component are then first analytically determined. The analysis would assume a uniform stress distribution through the plate thickness and that the crack direction is perpendicular to the tensile axial load in the plate. A stress spectrum generated by the manufacturer is then applied. The spectrum provides the changes in principal stresses with random loading. It is provided as a list of two parameters: a maximum fraction, $f_{\max }$, and a minimum fraction $f_{\min }$, of the maximum principal stress at each point along the crack path (straight line). $\Delta K$ at 0.05 in. $(1.27 \mathrm{~mm})$ may then be determined from Eq. (1) below

$$
\Delta K=\beta(\Delta \sigma) \sqrt{\pi a}
$$

where $\beta$ the geometry correction factor, is chosen from the closed form solution for a crack within a plate of similar geometry/loading and $\Delta \sigma$ is the initial stress variation within the spectrum. $\Delta \sigma$ is found from Eq. (2) below:

$$
\Delta \sigma=\left(f_{\max }-f_{\min }\right) \sigma_{h}^{\prime}
$$

where $\sigma_{h}^{\prime}$ represents the maximum principal stress value that would occur at the crack tip location during service loading without the presence of the crack. The crack growth rate, $d a / d N$, is then determined from the $d a / d N$ vs. $\Delta K$ curve for the load ratio (R) corresponding to $\Delta \sigma$.

\section{Fatigue Life Calculation using XFEM data}

The objective is to model crack growth using realistic geometry/service loads and predict the effect of an imperfection on the fatigue life of a bolted joint (Hi-Lok fastener) based on crack growth. The most widely accepted methods for incorporating the effect of residual stress on FCG are elastic superposition and effective stress intensity factors. The elastic superposition method has however not been successful in predicting the effect of residual stress on fatigue life for specimens subjected to beneficial compressive stress [1-14]. LaRue [15] incorporated plasticity-induced crack closure 
effects into the effective stress intensity factor method and obtained more accurate results compared to the elastic superposition method. Garcia et al. [6] also recently applied the effective SIF method using FEA predictions; their FE crack growth predictions were consistent with experimental results. The effective SIF method is chosen for this work. The analysis assumes that the crack grows under the linear region of the $\mathrm{da} / \mathrm{dN}$ vs $\Delta K$ curve, therefore the $\mathrm{FCG}$ threshold region was not considered.

In this work, a through-thickness crack of 0.05 in. $(1.27 \mathrm{~mm})$ was first introduced adjacent to the hole, perpendicular to the applied tensile loading and along the line of symmetry of the plate. A SIF range that is a function of the residual stresses, $\Delta K^{\prime}$, may be defined such that

$$
\begin{gathered}
\Delta K^{\prime}=K_{\max }^{\prime}-K_{\min }^{\prime} \\
R=\frac{K_{\max }^{\prime}}{K_{\min }^{\prime}}
\end{gathered}
$$

$K_{\max }^{\prime}$ and $K_{\min }^{\prime}$ were obtained directly from the XFEM analysis which includes the residual stress fields derived from coldworking and interference fit, $R$ is the stress ratio. Note that the predicted SIF is derived from a J-integral calculation. ABAQUS adopts a modified J-integral approach, similar to Lei et al. [16], that remains path independent in the presence of a residual stress field. $K_{\max }^{\prime}$ and $K_{\min }^{\prime}$ were chosen based on application of the maximum and minimum stresses within the spectrum to the XFEM model, yielding a load ratio of -0.19 . We were not seeking to predict fatigue lives under spectrum loading, but rather to examine the influence of imperfections on fatigue life under realistic loads. The assumption of a constant stress ratio based on the extremum values within the spectrum will therefore yield a conservative result regarding any observed effects.

The Harter T method was employed using experimentally derived $d a / d N$ vs $\Delta K$ curves published by Lopez [17] using stress ratios of -1 and 0.05 , to develop a $d a / d N$ vs $\Delta K$ curve for a stress ratio of -0.19 . An " $m$ parameter normalized", $\Delta K$ " was then defined as shown in Eq. (5) and a corresponding $d a / d N$ vs $\Delta K^{\prime \prime}$ curve plotted

$$
\Delta K^{\prime \prime}=\frac{\Delta K}{(1-R)^{(1-m)}}
$$

This simplifies the Walker Equation that incorporates the stress ratio, $R$, shown in Eq. (6) to Eqn. (7) below, thus allowing the constants $C$ and $n$ to be determined from a simple power law fit

$$
\begin{gathered}
\frac{d a}{d N}=C\left[\frac{\Delta K}{(1-R)^{(1-m)}}\right]^{n} \\
\frac{d a}{d N}=C\left[\Delta K^{\prime \prime}\right]^{n}
\end{gathered}
$$

The crack was extended incrementally ( 0.01 in., or 0.254 $\mathrm{mm}$ ) in the XFEM model and the resulting SIFS recorded at each extension. The $\Delta K^{\prime}$ computed at each increment were then be substituted for $\Delta K$ in Eq. (3). Using the XFEM SIF's allows for the incorporation of residual stress redistribution as the crack grows and the plastic strain history due to cold-working and interference. For each incremental increase in length, the number of cycles can be computed by integrating both sides of Eq. (6) to yield Eq. (8).

$$
\begin{aligned}
& \int_{a_{i}}^{a_{j}} \frac{d a}{(\sqrt{a})^{n}} \\
& =C \frac{(\beta \Delta \sigma \sqrt{\pi})^{n}}{\left((1-r)^{\left.1-m_{\text {avg }}\right)^{n}}\right.} \int_{N_{i}}^{N_{j}} d N
\end{aligned}
$$

For Eq. (6), the constants $C, n$ were determined from a power law fit to Eqn. (7) [R-squared $=0.996], \beta$ was determined using Eqn. (1) at the initial crack length, where $\Delta K$ was generated by the XFEM model at that length. An average value for the $m$ parameter, $m_{a v g}$, was determined using numerical integration of the numerator in Eq. (9). Note that the $\mathrm{m}$ vs $\Delta K$ relationship was obtained earlier using the Harter T method.

$$
m_{a v g}=\frac{\int_{\Delta K_{i}}^{\Delta K_{j}} m d(\Delta K)}{\Delta K_{j}-\Delta K_{i}}
$$

where $\Delta K_{i}$ and $\Delta K_{j}$ are the minimum and maximum $\Delta K^{\prime} s$ respectively.

\section{Results and Discussion}

\section{Coldwork Model Validation}

An image of the mesh and the resulting hoop stress field from the cold-working simulation is shown in Fig.4. The through thickness average elastic hoop strain was compared with those of the FEA results from Kang et al. and experimental data found from Ozdemir et al. [18]. The comparison shown in Fig.5 shows very good agreement between results.

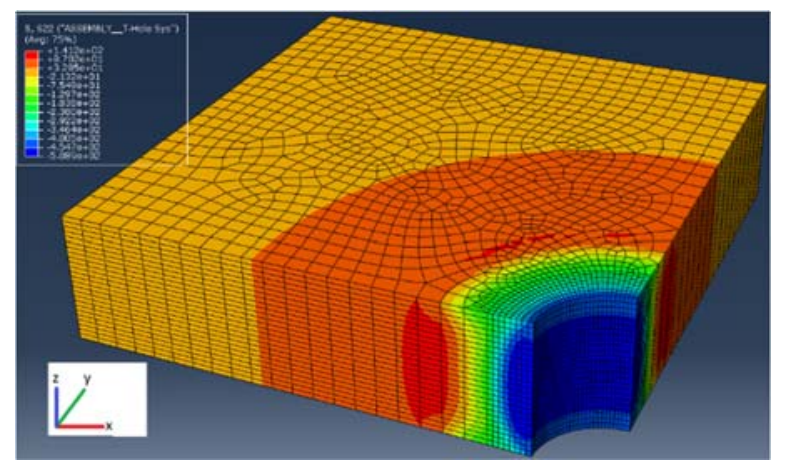

Figure 4. Mesh and hoop stress field (MPa) of cold-working model recreation

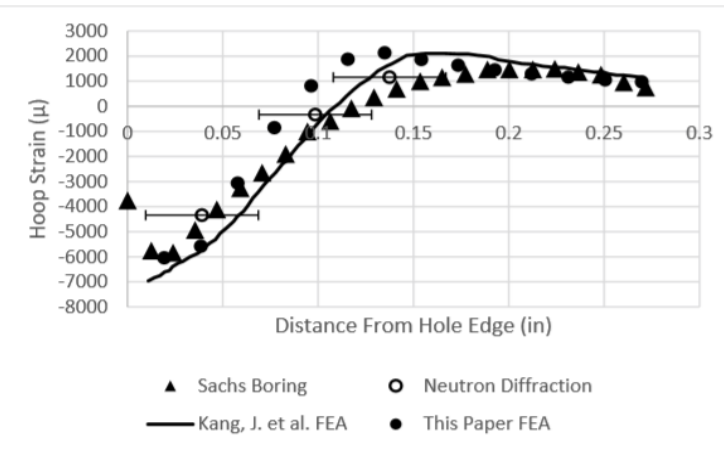

Figure 5. Comparison of theoretical and experimental through thickness average elastic hoop strain for cold-working model 


\section{Interference Model Validation}

An image of the mesh and resulting hoop stress field from a $0.5 \%$ interference fit simulation is shown in Fig. 6 . The bolt and elements outside the affected range of the interference fit were removed from the viewport for a better view of the hole face. The squeeze force was compared with those of the FEA results and experimental tests from $\mathrm{Bi}$ et al. [4]. The comparison shown in Fig.7 shows very good agreement between FEA predictions as well as experimental results.

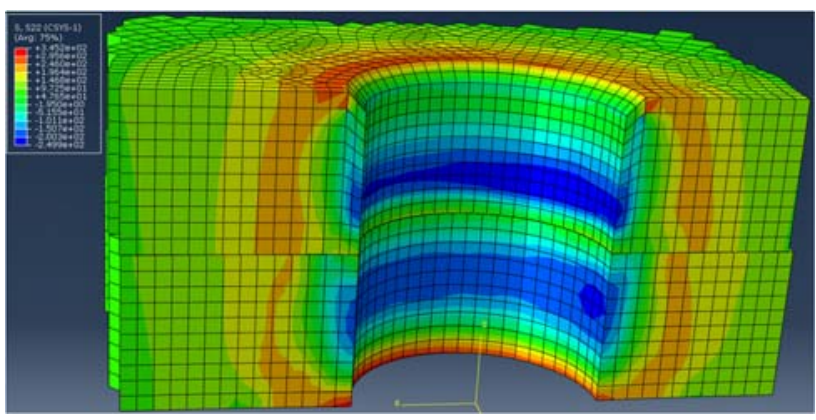

Figure 6. Mesh and hoop stress field (MPa) of interference fit model recreation $(I=0.5 \%)$

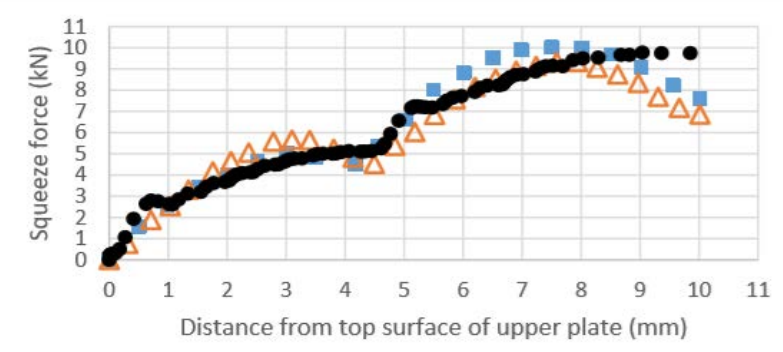

EBi, Y. et al. FEA $\triangle B$ Bi, Y. et al. Experimental $\bullet$ This Paper FEA

Figure 7. Comparison of theoretical and experimental squeeze force for interference fit model $(\mathrm{I}=1.5 \%)$

Fig. 8 provides a plot of the crack size vs number of cycles for the four fatigue cases. It can be observed that in all four cases, the crack growth rate jumps significantly when the crack length was within the range 0.1-0.15 in. (2.54-3.81 mm). The crack can therefore be considered to have stable growth up to some point within this range. A specific point at which instability occurs needs to be defined in order to establish a consistent fatigue failure criterion. It is reasonable to choose this as the point at which the difference in the number of cycles required to grow the crack across a 0.01 in. $(0.254 \mathrm{~mm})$ incremental step is less than $1 \%$. Using this definition for fatigue failure, the current model predicts that the fatigue life of this component (with no imperfection) increases by two orders of magnitude when residual stresses due to cold-work and interference are present. This result is reasonably consistent with the literature. Other studies have shown that residual stresses due to cold-working alone increase fatigue life by a factor of 10 or more [19]. The compressive residual stress field appears to have a strong influence on the effect of the imperfection (axial gouge) on fatigue life. When the residual stress field is present, the presence of the imperfection results in a $32 \%$ decrease in fatigue life. However, without the compressive residual stress field, the imperfection decreases the fatigue life by $23 \%$. The geometry of the axial gouge mimics a single edge crack at the edge of a central hole in a thin plate. A through crack at the edge of a hole in a thin plate is well understood and has been analyzed by many authors [20-22]. It is interesting that the presence of the axial gouge appears to cause a greater decrease in fatigue life when the residual stress is accounted for, compared to the decrease in fatigue life when residual stress is ignored. Recall the axial gouge was modeled as a triangular prism, the stress intensity would be highest at the apex of the triangular cross section. This is therefore the crack nucleation location and it likely occurs within the residual compressive stress zone. It is quite possible that the crack tip would experience some amount of cyclic reyielding during application of the fatigue load spectrum. Fujimoto [23] showed that residual stress field relaxation may be caused by overloads/underloads, or due to cyclic reyielding during crack growth. Similarly, Ball and Dueler [24] showed analytically and experimentally that the relaxation of residual stress fields can significantly reduce the predicted fatigue life (when relaxation is ignored).

The relaxation of the residual stress field as the crack grows from the apex of the axial gouge may account for the greater decrease in fatigue life due to the axial gouge when the residual stress field is accounted for.

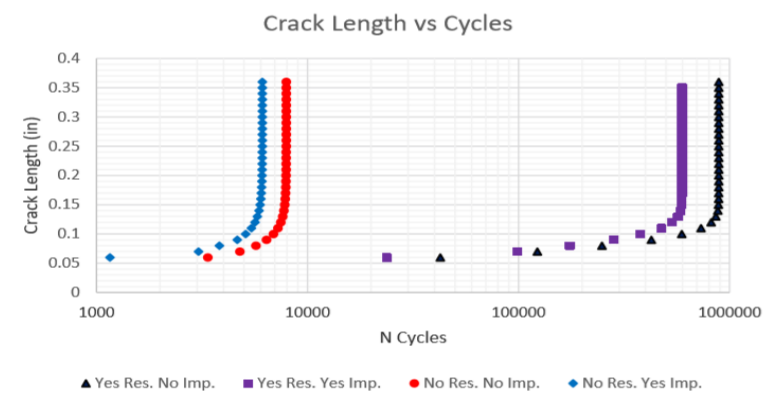

Figure 8. Crack Length vs Number of Cycles for: (i) Residual Stress, No imperfection, (ii) Residual Stress, Imperfection, (ii) No Residual Stress, No Imperfection and (iv) No Residual Stress, Imperfection

\section{Conclusion}

A 3-D isotropic elastic-plastic XFEM model of a stationary crack emanating from a hole in a rectangular plate with and without an imperfection present has been developed. The model includes initial residual stresses due to cold-work and interference fit. The Walker equation combined with XFEM derived SIF's at incremental crack growth lengths enable the prediction of fatigue crack growth with and without an imperfection present, for a constant amplitude cyclical load. The method accounts for residual stress redistribution as the crack grows and uses a modified J-integral to ensure path independence in a residual stress field. The presence of an axial gouge within a hole may result in a significant decrease in the component fatigue life under constant amplitude cyclical loading. When this imperfection is present, the decrease in fatigue life with a residual compressive stress field due to cold-work and interference fit is greater compared to the decrease in fatigue life without a residual stress field. This suggests that the beneficial residual stress field could and should be optimized depending on the expected stress spectrum type. However, the initial increase in fatigue life due to the presence of the residual stress field from cold work and interference fit is significantly greater than any decrease caused by this imperfection, which validates the effectiveness of cold work and interference fit as important tools to extend fatigue life. 


\section{Acknowledgements}

The authors would like to acknowledge the US Air Force Summer Faculty Fellowship program for funding this work. The authors would also like to acknowledge Dr. Kristina Langer, Dr. Thomas Spradlin and Dr. Eric Tuegel, for sharing their insights and knowledge regarding current methods used in the analysis of fatigue crack growth and residual stresses.

\section{References}

[1] CHAKHERLOU,T., MIRZAJANZADEH,M., ABAZADEH,B. S.K.: "An Investigation about Interference Fit Effect on Improving Fatigue Life of a Holed Single Plate in Joints," Eur J Mech A-Solid, 2010, Vol.29, No.4, pp.675-682.

[2] ZENG,C., TIAN,W., LIAO,W.: "The effect of residual stress due to interference fit on the fatigue behavior of a fastener hole with edge cracks," Eng Fail Anal, 2016, vol.66, pp.72-87.

[3] VALLIERES,G., DUQUESNAY,D.: "Fatigue life of cole-expanded fastener holes with interference-fit fasteners at short edge margins," Fatigue Fract Eng Mat Struct, 2015, Vol.38, No.5, pp.574-582.

[4] BI,Y., JIANG,J., KE,Y.: "Effect of interference fit size on local stress in single lap bolted joints," Adv Mech Eng, 2015, Vol.7, No.6, pp.1-12.

[5] ZHENG,B., YU,H., LAI,X., LIN,Z.: "Analysis of Residual Stresses Induced by Riveting Process and Fatigue Life Prediction," J Aircraft, 2016, Vol.53No.5, pp.1431-1438

[6] GARCIA,C., LOTZ,T., MARTINEZ,M., ARTEMEV,A., ALDERLIESTEN,R.B.R.: "Fatigue Crack Growth in Residual Stress Fields," Int J Fatigue, 2016, Vol.87, pp.326-338.

[7] JURY,D., RAMAKRISHNAN,R., CARTER,A.: "Rivet Installation and Hole and Faying Surface Quality," Delta Technical Operations, Atlanta, 2009.

[8] ATRE,A.: "A Finite Element and Experimental Investigation on the Fatigue of Riveted Lap Joints in Aircraft Applications", Atlanta: PhD thesis, Georgia Institute of Technology, 2006.

[9] Dassault Systèmes Simulia Corp, ABAQUS/CAE, .Providence, RI, USA.: Dassault Systèmes Simulia Corp, 2017

[10] KANG,J., JOHNSON,W., CLARK,D.: "Three-dimensional finite element analysis of the cold expansion of fastener holes in two aluminum alloys," J Eng Mat-T ASME, 2002,Vol.124, No.2, pp.140-145.

[11] HALL,L., SHAH,R., ENGSTROM,W.: "Fracture and fatigue crack growth behavior of surface flaws and flaws originating at fastener holes results and discussion," Technical report AFFDL-TR - Air Force Flight Dynamics Laboratory, Dayton, 1974.

[12] HSU,T., MCGEE,W., ABRESON,J.: "Extended study of flaw growth at fastener holes," Techical report AFFDL-TR-77-83, Dayton, 1977.

[13] CATHEY,W., GRANDT-JR,A.: "Fracture mechanics consideration of residual stresses introduced by coldworking fastener holes," J. Eng Mater-T ASME, vol. 120, no. 1, pp. 85-91, 1980.

[14] WANG,A., ZHANG,X.: "Predicting fatigue crack growth life for cold-worked holes based on existing closed-form residual stress models," Int J Fatigue, 2003, Vol.5, pp.285-1291,

[15] LARUE,J., DANIEWICZ,S.: "Predicting the effect of residual stresses on fatigue crack growth," Int J FatIgue, 2007, Vol.29, No.3, pp.508-515.

[16] LEI,Y., O’DOWD,N., WEBSTER,G.: "Fracture mechanics analysis of a crack in a residual," Int. J Fatigue, 2000, Vol.106, pp.195-216.

[17] LOPEZ,C.J.: Modeling of Residual Stress Fields and their Effects on Fatigue Crack Growth, Ottawa, Ontario: $\mathrm{PhD}$ thesis, Carleton University, 2015.

[18] OZDEMIR,A., WANG,D., EDWARDS,L.: "Measurement of the 3D Residual Stress Distribution at Split Sleeve Cold Expanded Holes," Int J Fatigue, 1995, Vol.17, No.8, pp.1144-1149.

[19] FINNEY,J.: "Cold Expansion and Interference for Extending the Fatigue Life of Multi-layer Metal Joints," Defence Science and Technology Organization, Aeronautical Research Lab ARL-RR-17, Melbourne, Australia, 1993

[20] GRANDT JR.,A., KULLGREN,T.: "A compilation of stress intensity factor solutions for flawed fastener holes," Materials Laboratory (AFWAL/HLL, MLS), Dayton, 1983.

[21] NEWMAN JR,J., RAJU,I.: "Stress intensity factor equations for cracks in three-diensional finite bodies," in Frachture Mechanics: Fourteenth Symposium-Volume I: Theory and Analysis, Los Angeles, CA, 1983.

[22] ZHAO,W., WU,X., YAN,M.: "Weight function method for three dimensional crack problems-II," Eng Fract Mech, 1989, Vol.34, No.3, pp.609-624.

[23] FUJIMOTO,W.: "Modeling the Formation and Growth of Cracks from Coldworked holes," J ASTM Int, 2006, Vol.3, No.5, pp.1-19.

[24] BALL,D., DOERFLER,M.: "Experimental and analytical studies of residual stress evolution and fatigue crack growth at cold expanded holes," USAF ASIP Conference, United States Air Force Aircraft Structural Integrity Program, Savannah, GA, 2003.

\title{
Uticaj geometrijskih nepravilnosti na brzinu rasta zamorne prsline $\mathbf{u}$ zoni otvora kod preklopnih spojeva hladno oblikovanih materijala sa čvrstim naleganjem
}

\begin{abstract}
Ovaj rad istražuje uticaj nepravilnosti na brzinu rasta zamorne prsline u preklopnim spojevima (Hi-Lok veza). Metod konačnih elemenata korišćen je za modeliranje procesa hladne obrade i čvrstog naleganja. Dobijeni numerički rezultati su u saglasnosti sa eksperimentalnim ispitivanjima i rezultatima objavljenim u stručnoj literaturi. Proširena metoda konačnih elemenata (XFEM) je potom korišćena za simulaciju Moda I otvaranja prsline u hladno oblikovanoj pravougaonoj ploči na mestu otvora sa čvrstim naleganjem. Ispitana su četiri slučaja zamora sa konstantnim opterećenjem: (i) bez zaostalih napona, bez nepravilnosti, (ii) bez zaostalih napona, sa nepravilnosti, (iii) sa zaostalim naponima, bez nepravilnosti i (iv) sa zaostalim naponima, sa nepravilnosti. Rezultati dobijeni upotrebom XFEM analize i jednačine Walker-a pokazali su da postojanje nepravilnosti u vidu aksijalnog kanala duž otvora može značajno smanjiti (23\%) zamorni vek komponente izložene cikličnom opterećenju konstantne amplitude. Postojanje zaostalih pritisnih napona u materijalu usled njegovog hladnog oblikovanja, odnosno usled čvrstog naleganja, dodatno smanjuje zamorni vek komponente.
\end{abstract}

